\title{
The Quality of Local Government Financial Statements and The Use of Financial Information in Decision Making
}

\author{
Raden Muhammad Rachmansyah Shadiqiawan \\ Faculty of Economics and Business \\ Universitas Padjadjaran \\ Sri Mulyani \\ Faculty of Economics and Business \\ Universitas Padjadjaran
}

\begin{abstract}
Financial statements contain information that is very helpful for users in making decisions. This study examines whether there are differences in the use of financial statement information decision making between the local government that obtain unqualified and qualified opinion for their financial statements. This study used the Mann Whitney test for hypothesis testing. Data was collected through a survey using a questionnaire on five local governments in West Java. The results of this study indicate that there are no significant differences in the use of financial statement information for local government decision-making, both in local governments that obtain unqualified and qualified opinions for their financial statements. This study also found that the financial statements most often used as a basis for decision making in the two groups of local governments are budget realization statement.
\end{abstract}

Keywords: Financial statements; Unqualified opinion; Qualified opinion; Utilization of financial information; Decision making.

\section{Introduction}

Financial statements have a role in providing information about the financial management of an entity during an accounting period. Financial Statements aim at presenting information for decision making and evaluating management performance (IASB, 2010; Atrill \& McLaney, 2011; Scott, 2012). Financial information is used as a consideration basis in decision making (Mahmudi, 2008). Likewise, for government agencies, the Local Government Financial Statements (LKPD) aims to provide information in economic, social, or political decision making and to evaluate management accountability or performance (Mardiasmo, 2009; KSAP, 2010). The financial statements of local government are considered fair based on Government Accounting Standards. An audit of LKPD conducted by the Supreme Audit Board (BPK) aims to improve the quality of information presented as a form of accountability to the public (Siregar, 2012).
Currently, LKPD has presented accounting information of good quality, namely with a large number of LKPDs that have obtained Unqualified Opinion from the results of audits conducted by the Supreme Audit Board. Based on a summary of the results of the examination in semester 1 of 2017 shows that LKPD in 2016 who obtained unqualified opinion amounted to $375(70 \%)$ of 537 LKPD (bpk.go.id). However, based on the result of research conducted by Agustijanti (2016) shows that local government financial statements are not utilized optimally as a basis for making economic decisions at the budgeting stage. Likewise, research result from Natalia and Marwata (2014) also shows that the financial statements presented by the Salatiga city government are underutilized in 12 decision contexts. The results of Agustijanti and also Natalia and Marwata's researches showed that there was no correlation between the quality of financial statements and their utilization. Therefore, in this study, the differences in the use of financial statement information in decision making in local 
governments that obtain unqualified and qualified opinions for their financial statements will be tested.

Local government financial statements provide information about the financial activities of government agencies, where the presentation must be following government accounting standards. The information presented must be relevant and reliable. Independent auditors assure the quality of information presented. The auditor's opinion is an indicator of the quality of the financial statements. The better the auditor's opinion on a financial statement, it can be said that the financial statement is getting better. It means that the information presented in the financial statements can be used as a basis for decision making by users, both decisions related to planning and performance evaluation. The results of this study indicate that the use of financial statement information by local governments in decision making, both for financial statements with unqualified and qualified opinions, does not have a significant difference. Another result of this study is the type of financial statements that is most often used as a basis for decision making by local governments whose get the unqualified and qualified opinion of their financial statements are the same, namely budget realization statement.

This research was conducted in several local governments in West Java. The regional government in West Java was chosen as a sample is financial statements for the year 2017. The majority obtained an unqualified opinion, namely 26 local governments, and only two local governments obtained qualified opinions. Also, the use of financial information by local governments in West Java has not been much studied. The contribution of this study is to provide an overview of the use of financial statement information in decision making by local governments, especially in West Java. Besides, it also provides an opportunity for subsequent researchers to examine the reasons for the use of financial statements as a basis for decision making by local governments. The results of this study are also expected to be used to provide education to local governments regarding any information that can be extracted from financial statements to make financial decisions.

\section{Literature review}

\section{Quality of Financial Statements}

High-quality financial statements are financial statements that, as a whole, including disclosures, present reasonable financial information on the operational activities and financial position of the entity (Robinson \& Munter, 2004). According to Arens et al. (2012), auditors' reports are usually used by users of financial statements because the information audited by independent auditors has been assumed to be complete, accurate, and unbiased. This statement is in line with the IASB and FASB standards councils which agree that information that can be independently verified is generally more useful (IASB, 2008). Among all the opinions issued by the auditor on the financial statements, the unqualified opinion will increase the confidence of the parliament, legislative council and other stakeholders towards the entity (ANAO, 2015). An unqualified opinion for users of financial statements is an important signal about the reliability of financial information in financial statements (IASB, 2014; 15).

\section{Utilization of Local Government Financial Statement Information in Decision Making}

According to Suwardjono (2011), information on financial statements will be useful if the intended user uses it as a basis for decision making. Clarity of purpose for whom the financial statements are presented and what is needed by users of financial information make information on financial statements useful. The financial reporting of government entities aims to provide information that can be utilized by users in terms of government accountability and performance, as well as for political, economic, and social decision making (Susanto, 2015). Measurement of the use of government financial statement information can be seen from the use of accounting information by users of financial statements (Jorge et al., 2008).

According to Suhartanto (2013), the budget realization statement can provide benefits in the form of feedback value and 
predictive value in the decision-making process by local government management related to evaluating budget performance. Budget realization statements can reflect information about the appropriateness of the government-managed budget and its realization (Natalia \& Marwata, 2014) while the information in the balance sheet can be the basis for decision-making relating to local government liquidity management, fixed asset management and liability/debt (Suhartanto, 2013). Natalia \& Marwata (2014) add that information in the balance sheet helps in managing assets and liabilities and to fulfill accountability obligations. It is consistent with the information presented in the balance sheet in the form of financial position, including information on assets, liabilities, and equity of government institutions (Government Regulation No. 71 of 2010).

Users also need information on sources and management capacity in obtaining cash flows to fund their activities without having to use external funding sources (PSAP 03) In determining historical cash flow information and alternative investments, can use historical investment decisions, because cash flow information is dynamic (Suhartanto, 2013). The Operations Statement (OS) presents information about the number of expenses for carrying out the entity's services and revenues during the reporting period. Information in the OS is useful for evaluating government performance in the form of efficiency and effectiveness in the acquisition and use of economic resources, as well as an increase or decrease in the equity of government agencies whereas Notes to Financial Statements, contain information regarding accounting policies, explanations of each heading in the financial statements, and other information that will provide users with an understanding of financial reporting entities (Natalia and Marwata (2014). Notes to Financial Statements in the form of information qualitative which explains and provides information under the quantitative information on the underlying financial statements.

The opinion of an independent auditor is a reflection that the financial statements presented by the auditee conform or not with applicable accounting standards. Financial statements that obtain unqualified opinion have received assurance from an independent auditor that the financial statements are following the standards, and the internal audits are conducted by auditee are already good, so that the financial information presented is free from bias and can be relied upon. Users of financial statements can trust the information presented in the financial statements and can make it as a basis for consideration in decision making. The lower the level of opinion given by the independent auditor, the reliability of the financial information presented becomes doubt. Based on the description above, the hypothesis formed in this study is there are significant differences in the use of financial statement information for decision making by local governments, between financial statements with unqualified and qualified opinions.

\section{Research methods}

This research used a descriptive verification method. A descriptive method, according to Whitney (1960), is the discovery of the right interpretation based on facts. The descriptive method describes the procedures applicable in society to a condition regarding relations, attitudes, activities, and methods that are ongoing and also the influence of a phenomenon, as well as problems that occur in society. Hypothesis testing used the Mann Whitney Test, with an alpha of 0.5. The sample in this study was the district and local/ city governments in West Java, but not all district and city governments in West Java were sampled in this study. District and city governments in West Java who received an unqualified opinion for the 2017 financial report are 26 local governments and only two local governments have qualified opinions. The sample in this study was taken based on the auditor's opinion obtained by the local government, as well as the geographical location of the local government, where the sample is only in the Great Bandung area. Sample in this study was selected using a purposive sampling technique, and five local governments were selected as a sample in this study, namely West Java Province, Cimahi City, Bandung City, West Bandung District, and Bandung District. 


\section{Results and Discussion}

The Comparison of Decision Making Between Local Governments That Get Unqualified and Qualified Opinions for Their Financial Statements

The research data were obtained from three local governments that received an unqualified opinion on their financial statements, namely West Java Province, Bandung District, and Cimahi City, and two local governments that received qualified opinion, namely Bandung City and West Bandung District. Based on the results of the questionnaire, it is known that the type of decisions that are most often taken based on information in the budget realization statement for Local Governments that get unqualified and qualified opinions are the same, namely assessing the realization of budget absorption. Whereas the type of decision that is most rarely taken based on budget realization statement information for Local Governments that get unqualified opinion is the decision to predict economic resources that will be received in the coming period. While for Local Governments that get qualified opinions, is a decision for evaluating government performance in terms of efficiency and effectiveness of budget use.

The types of decisions that are most often and rarely taken based on information in the balance sheet for local governments that obtain unqualified and qualified opinions are different. Local Governments that get unqualified opinion, the decision most often taken is determining how to meet the needs of goods and services. Meanwhile, the decision that is rarely taken is the decision on the utilization of the government's property, which is not used according to the tasks and functions of the Satuan Kerja Perangkat Daerah (SKPD). While for Local Governments that obtain a qualified opinion, the decision most often is taken is the use of government's goods determined by the region to the user following the SKPD's tasks, evaluating changes in the net asset of a reporting entity and the government's financial structure. Whereas, the decision that rarely taken is the government's debt procurement. Local Governments have utilized the balance sheet information with quite optimal.
The types of decisions that are most often and rarely taken based on cash flow statement information for local governments that obtain unqualified and qualified opinions are different also. Local Governments that get unqualified opinions, the decision most often taken is to assess the government's ability to generate government cash inflows. Meanwhile, the decision most rarely taken is to predict the amount of cash flow in the future. For the Local Governments that get a qualified opinion, the most frequently taken decision is to evaluate past financial investment activities for future planning.

The type of decision that is most often taken is based on operations statement information for Local Governments that obtain unqualified and qualified opinions are different. For Local Governments that get unqualified opinion, the information is to predict operating income that will be received to fund activities in the coming period. Whereas for the Local Governments that get a qualified opinion, the information is to evaluate the efficiency of obtaining and using economic resources. For the types of decisions that are rarely taken based on operation statement information for the two categories of Local Government is the same, namely evaluating the efficiency of obtaining and using economic resources. The Operations Statement has been utilized quite optimally by the Local Governments.

The type of decision that is most often taken based on the information of notes to financial statements for local governments that get unqualified and qualified opinions are different. Local governments that get unqualified opinions use the information for the understanding of the accounts on the financial statements that affect decision making. Whereas for the Local Governments that get the qualified opinion, it is for the understanding of the policies and strategic plans of the Government. While the type of decision that is rarely taken based on the information for the two categories, Local Government is the same, namely evaluating the increase and equitable distribution of public income. 
Comparison of The Results of Responses Between Local Governments That Get Unqualified and Qualified Opinions for Their Financial Statements

To find out the total score from the results of respondents' responses on the use of financial information for decision making between the Local Governments that get unqualified and qualified opinions is presented in Table 4.

Table 4. The Comparison of Recapitulation of Respondents Response Scores

\begin{tabular}{|c|c|c|c|c|c|c|c|}
\hline & $\begin{array}{c}\text { Local } \\
\text { Government }\end{array}$ & $\begin{array}{c}\text { Budget } \\
\text { Realization } \\
\text { Statement }\end{array}$ & $\begin{array}{c}\text { Balance } \\
\text { Sheet }\end{array}$ & $\begin{array}{c}\text { Cash Flows } \\
\text { Statement }\end{array}$ & $\begin{array}{c}\text { Operations } \\
\text { Statement }\end{array}$ & $\begin{array}{c}\text { Notes to } \\
\text { Financial } \\
\text { Statement }\end{array}$ & $\begin{array}{r}\text { Total } \\
\text { scores }\end{array}$ \\
\hline & $\begin{array}{l}\text { West Java } \\
\text { Province }\end{array}$ & $94,4 \%$ & $83,1 \%$ & $81,3 \%$ & $80 \%$ & $86,4 \%$ & $85 \%$ \\
\hline \multirow[t]{3}{*}{$\begin{array}{l}\text { Unqualified } \\
\text { opinion }\end{array}$} & $\begin{array}{l}\text { Bandung } \\
\text { District }\end{array}$ & $90 \%$ & $91,9 \%$ & $91,6 \%$ & $92,2 \%$ & $88,6 \%$ & $91 \%$ \\
\hline & Cimahi City & $87 \%$ & $81,6 \%$ & $79,6 \%$ & $78,3 \%$ & $79,5 \%$ & $81,4 \%$ \\
\hline & Total & $89,9 \%$ & $85,5 \%$ & $83,9 \%$ & $83,2 \%$ & $84,2 \%$ & $85,4 \%$ \\
\hline \multirow{3}{*}{$\begin{array}{l}\text { Qualified } \\
\text { opinion }\end{array}$} & Bandung City & $67 \%$ & $59,4 \%$ & $65,4 \%$ & $65,0 \%$ & $63,0 \%$ & $63 \%$ \\
\hline & $\begin{array}{l}\text { Bandung } \\
\text { Barat District }\end{array}$ & $67,30 \%$ & $65,9 \%$ & $66,7 \%$ & $67,7 \%$ & $67,3 \%$ & $66,8 \%$ \\
\hline & Total & $67,10 \%$ & $62,2 \%$ & $66 \%$ & $66,2 \%$ & $64,9 \%$ & $64,8 \%$ \\
\hline
\end{tabular}

Source: Processed Questionnaire Data (2019)

Based on information in table 4 indicates that the local government financial statements most often used by the two categories of local government have no difference, namely the budget realization statement. Whereas the local government financial statements most rarely used as a basis for decision making have a difference, where for the local governments that get an unqualified opinion for their financial statement is the Operations Statement, while for the local governments that get for their financial statement qualified opinion is the Balance Sheet. However, for local governments that get unqualified opinions, the information in the balance sheet is often used as a basis for decision making also.

Table 5. Comparative Use of Financial Statements Information in decision making

\begin{tabular}{lc}
\hline Statistics Test & Local Government Financial Statements \\
\hline Mann-Whitney U & 1,000 \\
Wilcoxon W & 4,000 \\
Z & $-1,155$ \\
Asymp. Sig. (2-tailed) & 0,248 \\
Exact Sig. [2*(1-tailed Sig.)] & 0,400 \\
\hline a. Grouping Variable: Opinion &
\end{tabular}

From the results of data comparison testing using the Mann-Whitney test, the Sig. Value of 0.248 , which is higher than the alpha value $(5 \%)$. Then with a confidence level of $95 \%$, it can be decided to accept Ho and reject $\mathrm{Ha}$, which means that there is no significant difference in the use of financial information for decision making between Local Governments that get an Unqualified Opinion and Qualified opinion for their financial statements. In other words, the quality of Local Government Financial Statements does not a significant influence on the use of financial information for decision making. 
Table 6. Comparison of the use of Budget Realization Statement Information in decision making

\begin{tabular}{lc}
\hline Statistics Test $^{\text {a }}$ & Budget Realization Statement \\
\hline Mann-Whitney U & 1,000 \\
Wilcoxon W & 4,000 \\
Z & $-1,155$ \\
Asymp. Sig. (2-tailed) & 0,248 \\
Exact Sig. [2*(1-tailed Sig.)] & 0,400 \\
\hline a. Grouping Variable: Opinion & \\
\hline
\end{tabular}

The test of comparison of budget realization statement information using the Mann-Whitney test produces the Sig. Value of 0.248 , which is higher than the alpha value $(5 \%)$, where with a $95 \%$ confidence level, Ho was accepted, and Ha was rejected. It means that there is no significant difference in the use of financial information of the Budget Realization Statement for decision making between the local governments that get unqualified and qualified opinions for their financial statements.

The same results were also obtained for the comparative test for the utilization of financial information presented in the balance sheet, cash flow statement, operations statement, and notes to the financial statements in decision making. All refused $\mathrm{Ha}$ and accepted Ho, which meant that there was no difference in the use of financial information in local governments that received unqualified and qualified opinions on their financial statements. The same result is obtained because the auditor's opinion is given for the entire financial statements of the auditee, not for each component of the financial statements.

There is no difference in the use of financial statement information in decision making by regional governments that obtain unqualified and qualified opinions on their financial statements, in line with the results of Agustijanti and also Natalia and Marwata's research, that there is no correlation between the quality of financial statements and their utilization. Nearly all local governments use budget realization statements for their decision making than information presented in other components of the financial statements. Budget realization statement is one of the components of financial statements that uses a cash basis, besides cash flow statements. Although the two financial statements are cash-based, the budget realization statement shows a comparison between the budget and its realization. Comparing the budget realization with the budget makes it easy for the local government to evaluate the implementation of the budget. The results of this evaluation assist local governments in planning and budgeting for the next period.

Budget realization statement is a report that has been made since the Government of Indonesia still applies cash basis accounting because the Indonesian Government has applied cash toward accrual accounting in the 2010 - 2014 fiscal year, and accrual accounting has been applied since the 2015 fiscal year. Thus, government agencies familiar with the budget realization statement compared to other components of the financial statements. Therefore, almost all local governments utilize the financial information contained in the budget realization statement for local government financial decision making, both at the planning and evaluation stages. In addition, maybe at this time, the local government is still in the stage of studying the contents of the financial information presented in other financial statement components, which can later be used as a basis for decision making. So that independent auditor opinion has not had much effect on the use of financial information which is presented in the financial statements of local governments. 


\section{Conclusion, Limitation, and Suggestion}

Based on the results of data analysis derived from the respondents' perceptions above, it can be concluded that there is no significant difference in the use of financial statement information for decision making for the two categories local governments namely local governments that get unqualified opinion and qualified opinions for their financial statement. So it can be concluded that the quality of local government financial statements does not have a significant influence on the use of financial information in decision making.

The limitation of this study is that the sample is too small so that it can only use nonparametric tests for hypothesis testing. If the number of samples is more significant than the sample was used in this study, there is a possibility of getting different research results. To reduce data bias, the next researchers should use observation and interview techniques in data collection related to the use of financial information for decision making.

\section{References}

Agustijanti, Diah. 2016. Studi Eksplorasi Pemanfaatan Laporan Keuangan Pemerintah Daerah Dalam pengambilan Keputusan Ekonomi Pada Pemerintah Kabupaten Klaten. Repository: Universitas Gadjah Mada

Anwar, Suroyo. 2009. Pemahaman Individu, Observasi, Checklist, Interview,. Kuesioner dan Sosiometri. Yogyakarta: Pustaka Pelajar.

Arens, et al. (2012). Auditing and Assurance Service an Integrated Approach. Ed $14^{\text {th }}$ edition Pearson Education Inc: New Jersey.

Arikunto S, 2006. Prosedur Penelitian Suatu Pendekatan Praktik, Ed Revisi VI, Penerbit PT Rineka Cipta, Jakarta.

Atrill and McLaney, 2011. Management Accounting for Decision Makers. Prentice Hall

Badan Pemeriksa Keuangan Republik Indonesia. Accessed 20 September 2018. Ikhtisar Hasil Pemeriksaan
Semester (IHPS). Retrieved from BPK RI: http://www.bpk.go.id/ihps

Baldric Siregar. 2015. Akuntansi Sektor Publik (Akuntansi Keuangan Pemerintah Daerah Berbasis Akrual). Edisi Pertama.Yogyakarta: Unit Penerbit dan Percetakan Sekolah Tinggi Ilmu Manajemen YKPN.

Baridwan, Zaki. 2008. Intermediate Accounting. Edisi 8. Yogyakarta: BPFE

Biset. 1998. Pemangku Kepentingan. Accessed 07 September 2011, https://id.wikipedia.org/wiki/Pemangk u_kepentingan

Dan M. Guy, C. Wayne Alderma, dan Alan J. Winters. 2002. Auditing. Edisi kelima. Alih bahasa Paul A. Rajoe, Erlangga. Jakarta.

Erlina, Rasdianto. 2013. Akuntansi Keuangan Daerah Berbasis Akrual. Penerbit Brama Ardian

F.L, Whitney.1960. The Elements of Resort. Asian Eds. Osaka: Overseas Book Co.

Fahmi, Irham. 2011. "Analisis Laporan Keuangan". Bandung: Alfabeta.

Fama, E. F., \& Jensen, M. C. (1983). Agency Problems and Residual Claims. Journal of Law and Economics, Vol.26, No.2.

Freeman, R. Edward. 1984. Strategic Management A Stakeholder Approach. Boston: Pitman Publishing, Inc.

Harahap, Sofyan Syafri. 1991. Auditing Kontemporer. Jakarta; Erlangga.

Ikatan Akuntansi Indonesia (IAI). 2004. Pernyataan Standar Akuntansi Keuangan (PSAK ). Jakarta: Salemba Empat.

Jones, Rowan, and Maurice Pendlebury, (2000), Public Sector Accounting, Fifth Edition, Pearson Education Ltd., England.

Jorge, Susana M., Joao B. da Costa Carvalho, and Maria J. Fernandes, (2008), "From Cash to Accrual in Portuguese Local Government Accounting: What Has 
Truly Changed," Techne, Vol. VI, No. 10, page. 239-262.

Mardiasmo. (2009). Akuntansi Sektor Publik. Yogyakarta: Andi

Margaretha, Farah. 2011. Teori Dan Aplikasi Manajemen Keuangan Investasi dan Sumber Dana Jangka Pendek. Jakarta: Grasindo Gramedia Widiasarana Indonesia

Moe, T. M. 1984. The New Economics of Organization. American Journal of Political Science 28(5): 739-777.

Mulyadi dan Puradireja. (2002). Auditing. Edisi 6. buku 1; Jakarta; Salemba Empat.

Natalia, C., \& Marwata. (2014). Academics' Perception of the Decision Usefulness and Understandability of the Salatiga Government Financial Statement. Economics \& Business Research Festival, 1593-1619.

Nur, Marzully, dan Denies Priantinah.2012. Analisis Faktor-Faktor yang Mempengaruhi Pengungkapan Corporate Social Responsibiity di Indonesia (Studi Empiris Pada Perusahaan Berkategori High Profile yang Listing di Bursa Efek Indonesia). Jurnal Nominal, Volume 1, No. 1, 2234.

Parwanto, Harto 2017. Pengaruh Hasil Pemeriksaan BPK terhadap Kinerja Keuangan Pemerintah Daerah. ISSN: 2337-3806.

Robinson, T R dan P Munter. 2004. Financial Reporting Quality: Red Flags and Accounting Warning Signs. Commercial Lending Review. Vol. 19. No. 1: 2-15.

Rudiantoro and Siregar, 2012. Kualitas Laporan Keuangan UMKM Serta Prospek Implementasi SAK ETAP. Jurnal Akuntansi Dan Keuangan Indonesia, Vol 1, No. 9

Rutoto, Sabar. 2007. Pengantar Metedologi Penelitian. FKIP: Universitas Muria Kudus
Scott,William R.2000.Financial Accounting Theory.USA:Prentice-Hall.

Sekaran, Uma. (2011). Research Methods for business Edisi I and 2. Jakarta: Salemba Empat.

Setiyanti, SW. (2012). "Jenis-jenis Pendapat Auditor (Opini Auditor)". Jurnal STIE Semarang. 4, (2), 23-25.

Standar Auditing Seksi 508.1. SPAP. 2001

Sugiyono. 2010. Metode Penelitian Pendidikan Pendekatan Kuantitatif, kualitatif, dan $R \& D$. Bandung: Alfabeta

Sugiyono. 2011. Metode Penelitian Kuantitatif, Kualitatif dan $R \& D$. Bandung: $\quad$ Afabeta

Suhartanto. (2013). Efektivitas Laporan Keuangan Pemerintah Daerah dalam Mendukung Pengambilan Keputusan Manajemen Pemerintah Daerah. Pusdiklat Pengawasan BPKP.

Susanto, D and Djuminah (2015). The usefulness of Local Government Financial Statements for Regional Development Planning Process (An Empirical Study Against the Head of the District Development Planning Agencies in Java and Madura). 2nd Global Conference on Business and Social Science-2015 (pp. 75- 80). Bali: Elsevier.

Suwardjono. 2011. Teori Akuntansi Perekayasaan Pelaporan Keuangan. Edisi ketiga cetakan kelima. Yogyakarta: BPFE Yogyakarta.

Trihani, I. (2018). Analisis Manfaat Basis Akrual dan Basis Kas Menuju Akrual dalam Pengambilan Keputusan Internal Pemerintah Daerah. Padang. Universitas Padang.

Winarna, Jaka dan Sri Murni. 2014. Persepsi User Terhadap Laporan Keuangan Pemerintah Daerah (Studi Empiris di Eks Karisidenan Surakarta). Journal of Rural and Development, V (1), 15. 
Yusuf, Pawit M. 2010. Komunikasi Instruksional : teori dan praktek. Jakarta : PT. Bumi Aksara

Zimmerman, J. L. (1977). The municipal accounting maze: an analysis of political incentives. Journal of Accounting Research, 107-144. 